\title{
Synchronized occurrence of oncocytic variant of papillary carcinoma of the thyroid and esophageal squamous cell carcinoma metastasis: case report
}

\author{
Tiroidde senkronize tiroid papiller karsinom onkositik varyant ile özofagus skuamöz hücreli \\ karsinom metastazı birlikteliği: olgu sunumu
}

Gülay Bulut ${ }^{1}$, Remzi Erten ${ }^{1}$, İnci Buğday ${ }^{1}$, Mehmet Deniz Bulut ${ }^{2}$, Irfan Bayram ${ }^{1}$, Osman Toktaş ${ }^{3}$

\begin{abstract}
Metastasis to the thyroid is extremely rare. In recent years, there is an increase in metastasis to the thyroid. This may be related with common use of the fine-needle aspiration biopsy. Synchronized occurrence of the oncocytic variant of papillary carcinoma of the thyroid and metastasis into thyroid, especially of esophageal origin, is very rarely seen. We present a rare case of a 56-yearold female in whom a primary esophageal squamous cell carcinoma gave rise to a metastatic palpable mass in the left lobe of thyroid gland and oncocytic variant of papillary carcinoma of the thyroid in the right lobe of thyroid gland. J Clin Exp Invest 2015; 6 (4): 396-399
\end{abstract}

Key words: Metastasis, papillary carcinoma, squamous cell carcinoma, thyroid

\section{INTRODUCTION}

Thyroid is an intensively vascularized organ. However, metastasis to thyroid is rather rare. Metastasis into thyroid tissue may be through hematogenous or lymphatic spread and is usually multifocal [1]. According to literature, metastasis into thyroid was identified in 1.4-3\% of all surgery specimens due to thyroid malignancy, this ratio amounts for 1.9-24\% in autopsy series [2]. Generally, origin of metastasis to thyroid include kidneys, lungs, uterus and skin (melanoma) while the most frequent origins of metastasis in autopsy series are breast, lungs and skin (melanoma) [3-5]. Synchronization with the neoplasms of the thyroid and the metastasis of another tissue tumor into thyroid are very rare. In the litera-

\section{ÖZET}

Tiroide metastaz oldukça nadirdir. Son yıllarda tiroide metastazda artış görülmektedir. Bu da ince iğne aspirasyon biyopsisinin daha sık kullanılıyor olmasıyla ilişkili olabilir. Senkronize tiroid papiller karsinom onkositik varyantı ile özellikle özogafus kaynaklı tiroide metastaz birlikteliği oldukça nadir görülür. Bu yazıda 56 yaşında bayan hastada, tiroid sol lobda metastatik palpabl kitle gelişimine sebep olan primer özofageal skuamöz hücreli karsinom ile sağ lobda tiroid papiller karsinom onkositik varyant birlikteliğini sunmaktayız.

Anahtar kelimeler: Metastaz, papiller karsinom, skuamöz hücreli karsinom, tiroid

ture review, five cases of metastasis of esophagus carcinoma into thyroid were found that is four being English publications and one Eastern Chinese publication. With this paper, we report for the first time the co-occurrence of oncocytic variant, a rare type of primary papillary carcinoma of the thyroid, and metastatic squamous cell carcinoma of the esophagus.

\section{CASE REPORT}

A 56-year-old female patient, who was under followup based on the diagnosis of multinodular goiter, presented to the clinic due to cough, shortness of breath, difficulty in swallowing and increased swelling in her neck. As palpable, hard nodules in the

\footnotetext{
${ }^{1}$ Department of Pathology, Yuzuncu Yil University Faculty of Medicine, Van, Turkey

${ }^{2}$ Department of Radiology, Yuzuncu Yil University Faculty of Medicine, Van, Turkey

${ }^{3}$ Department of General Surgery, Yuzuncu Yil University Faculty of Medicine, Van, Turkey
}

Correspondence: Gulay Bulut,

Yuzuncu Yil University, Medical Faculty, Department of Pathology, 65000, Van, Turkey Email: drgulaybulut@yahoo.com

Received: 01.10.2015, Accepted: 15.11.2015

Copyright @ JCEI / Journal of Clinical and Experimental Investigations 2015, All rights reserved 
right and left lobes of the thyroid were identified in her examination. The ultrasonography revealed enlargement of thyroid lobes and nodules had a wide spectrum of appearances. They were most often hypoechoic, some of isoechoic and commonly underwent cystic degeneration. She underwent bilateral total thyroidectomy and left lateral neck dissection based on a pre-diagnosis of thyroid carcinoma. Peri-operatively, bilateral multiple nodules were observed with the one in the left lobe of the thyroid sized at $3 \times 2 \times 2 \mathrm{~cm}$ and the one in the right lobe at $8 \times 5 \times 5 \mathrm{~cm}$; the larger one was on the right side. A hard, massive lesion sized at $4 \times 5 \mathrm{~cm}$ with unclear contours, which showed infra-clavicular extension, considered to have originated from thyroid, gave the impression of a conglomerated lymphadenopathy, posteriorly invading the esophagus and laterally invading the carotid sheath, was observed. Furthermore, multiple lymphadenopathies at all levels in the left lateral neck site were also observed.

The specimen consisted of the right lobe and left lobe of the thyroid gland and weighed $73 \mathrm{~g}$. An ill-defined grayish white flesh mass, measuring $5 \times 3.5 \times 3 \mathrm{~cm}$, was noted in the right lobe. The cut surface of the tumor showed a gray-white encapsulated mass and was completely filled with brown necrotic material and observed to have occasional papillary projections on its walls. The cut surface of the tumor showed the solid, gray-white colored, sized at $2 \times 1.5 \times 1.4 \mathrm{~cm}$, adjacent to thyroid capsule in the left lobe. Ten structures consistent with lymph node from seven pieces of tissue sent with the lymph node registered were dissected.

In the histopathological examination, papillary structures containing fibro-vascular cores and oncocytic cells with nuclear grooves and intranuclear

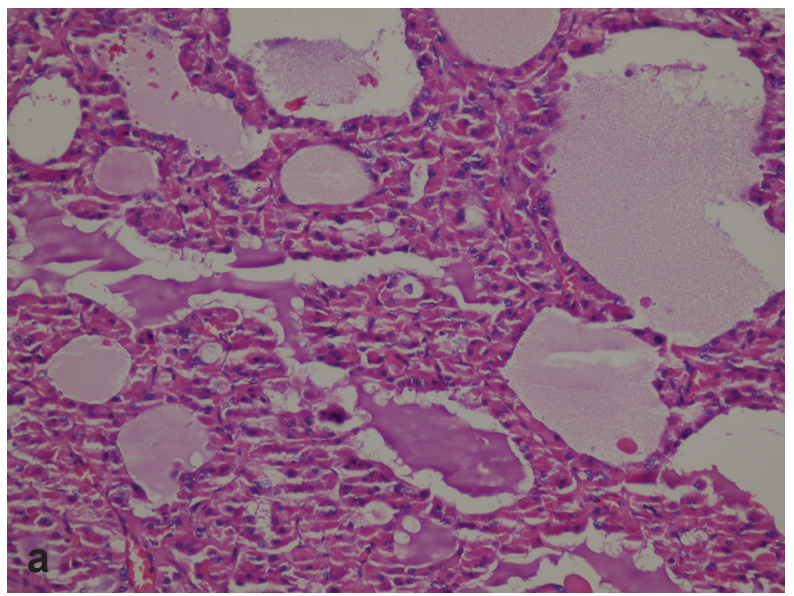

inclusions were observed at right lobe of thyroid. Irregularity of nuclear contours, enlargement nucleus, overlapping, including grooves and nuclear pseudoinclusions presented (Figures 1a-b). The nuclei typically were clearing and ground glass appearance. This focus was diagnosed as oncocytic variant of papillary carcinoma of the thyroid. As for the cross-sections obtained from the left lobe, sites that were consistent with metastasis of squamous cell carcinoma where necrosis and lymphovascular invasion were also identified, were observed (Figure 2). The tumor cells were cohesive and arranged in sheets and nests. Keratinization was not easily identified in the tumor. Desmoplastic stromal fibrosis was noted. In the immunohistochemical examination, the tumour cells expressed positive staining with HMW-CK (Figure 3), Cytokeratin 19 and p63 (Figure 4) while staining was not observed with the stains CK7, CK20, thyroglobuline (Figure 5), TTF-1 and HBME1. Metastasis of squamous cell carcinoma was identified in one of the lymph nodes. The endoscopic examination performed as part of patient screening studies that were consequently carried out in the patient in order to identify the primary organ of the squamous cell carcinoma in the left lobe revealed the following: $15 \times 10-\mathrm{mm}$ diameter polypoid lesion with a surface that was partially normal and partially covered by eroded mucosa at $20 \mathrm{~cm}$ in the esophagus as of the incisors and 7-mm-diameter vegetating mass with irregular borders next to the lesion. Four endoscopic biopsy samples were collected from this site. Histopathological examination of the endoscopic biopsy material revealed moderately differentiated squamous cell carcinoma (Figure 6). The primary organ of the squamous cell carcinoma detected in the left lobe of the thyroid was assessed to be the esophagus.

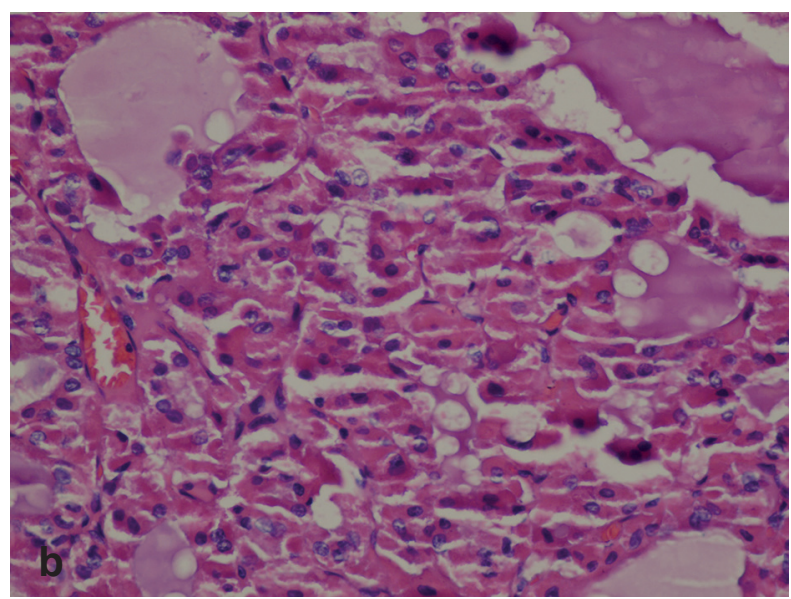

Figure 1a-b: Hematoxylin and Eosin staining showing oncocytic variant of papillary thyroid carcinoma (a: H\&E x 200) (b: H\&E x 400) 


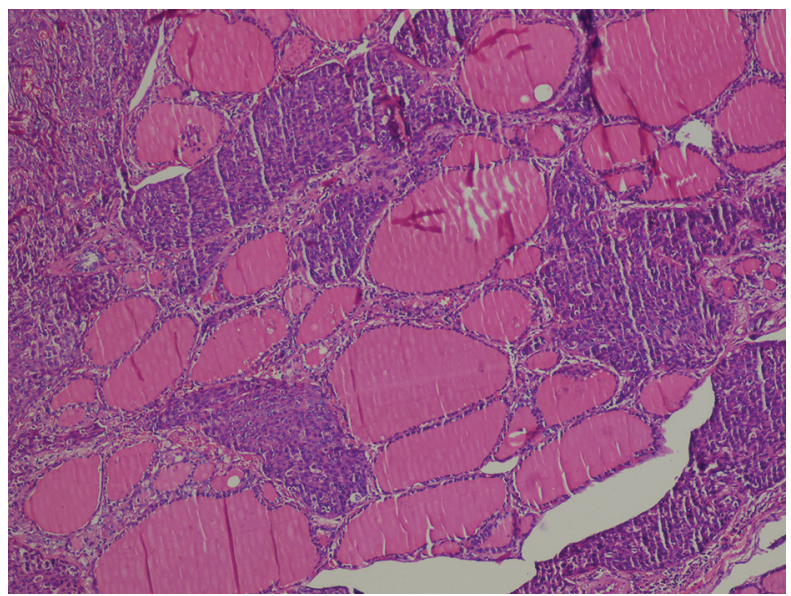

Figure 2: Hematoxylin and Eosin staining showing poorly differentiated squamous cell carcinoma (H\&E x 100)

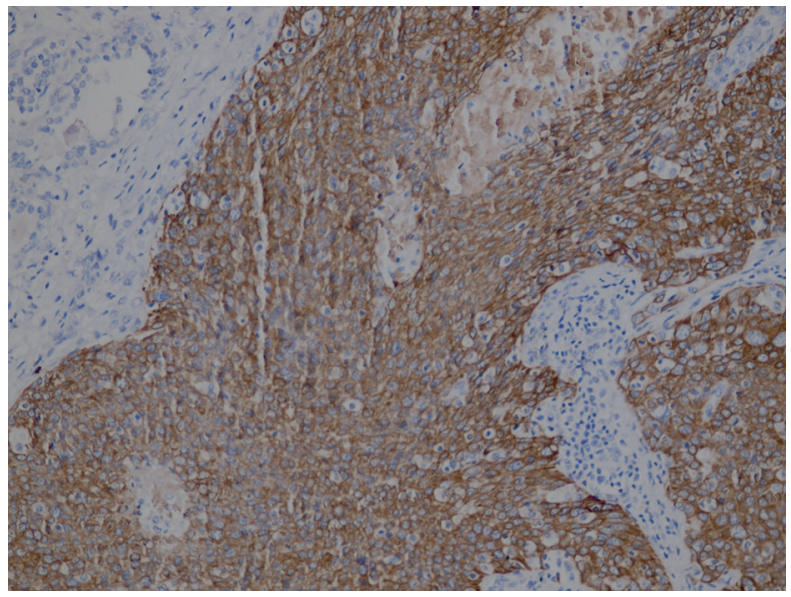

Figure 3: The tumor cells of the squamous cell carcinoma component strongly expressed HMWCK (HMWCK x 200)

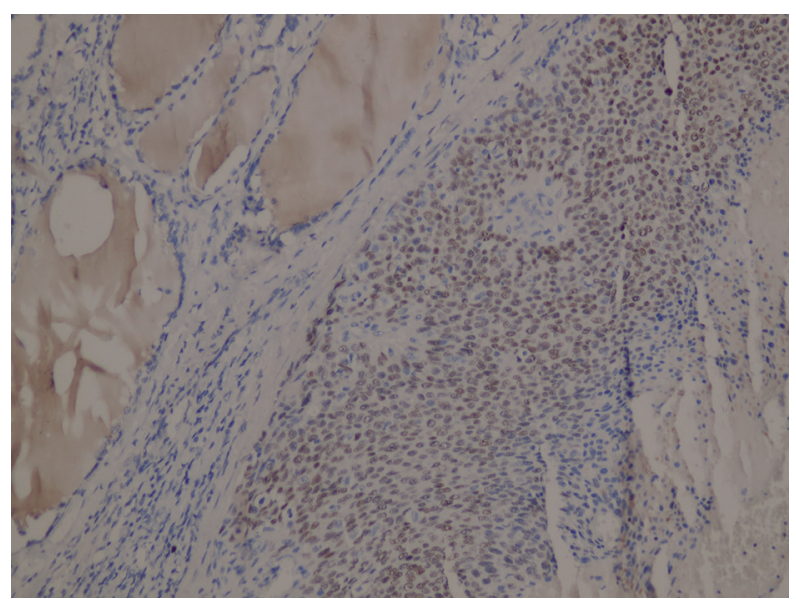

Figure 4: P63 positive section of a squamous cell carcinoma (P63 x 200)

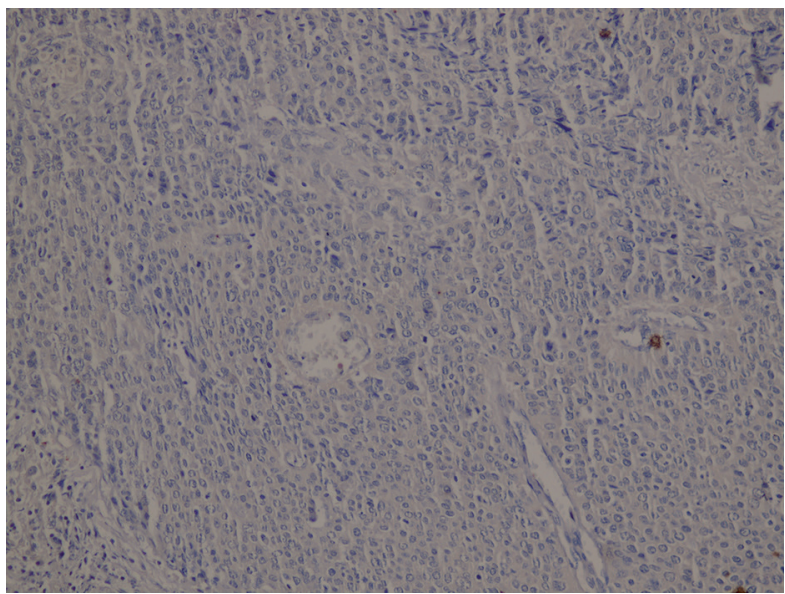

Figure 5: Thyroglobulin-negative section of a squamous cell carcinoma (Thyroglobulin $\times 200$ )

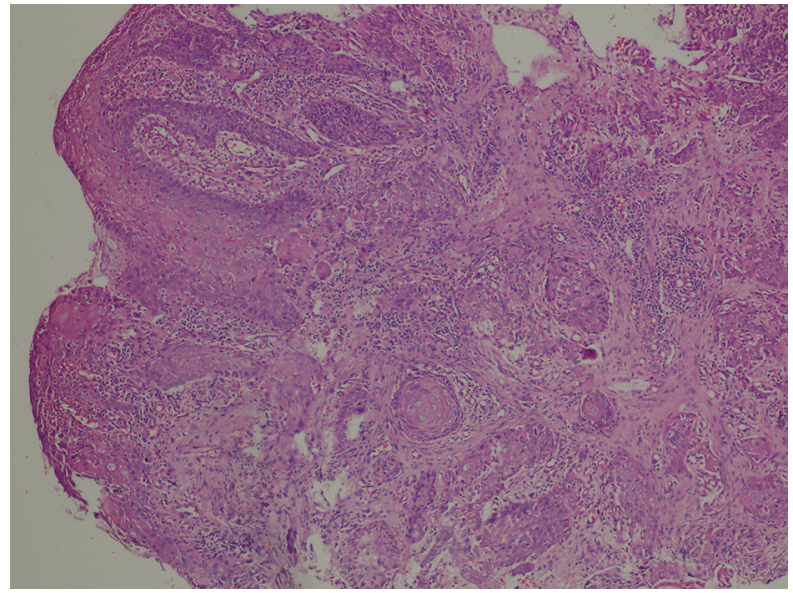

Figure 6: Histopathologic findings of primary squamous cell carcinoma in the esophagus (H\&E x 100)

\section{DISCUSSION}

Metastasis of gastrointestinal system malignancies into thyroid has a rather low incidence and most of them are from the colo-rectum [2]. If the cytology and histology findings seem unusual with respect to determining the primary organ in neoplasms of the thyroid, potential for metastasis should absolutely be taken into account. History of past malignancy, infiltrative borders and tumor embolism into lymph veins may aid in the diagnosis of metastasis $[6,7]$. Direct metastatic extension into the thyroid may be via hematogenous or lymphatic spread and it is generally multifocal [1]. The non-thyroid malignancies that most often metastasize into the thyroid include renal cell carcinoma $(48.1 \%)$, colorectal $(10.4 \%)$, lung $(8.3 \%)$, breast carcinomas $(7.8 \%)$ 
and sarcomas (4\%) [2]. Additionally, coexistence of the own neoplasms of the thyroid and metastasis of another tumor into the thyroid are rather rare [8]. The coexistence of esophagus and thyroid or metachrone cancer as in our case have been reported much more rarely.

Papillary carcinoma is the most frequent primary malignant neoplasm of the thyroid gland. Several morphological variants have been defined according to the structural, cellular and stromal characteristics and growth pattern [9]. In our case, oncocytic variant, a rare sub-type of papillary carcinoma, was identified. This variant constitutes $1-11 \%$ of all papillary carcinomas and the difference between these numbers probably stems from the different qualification criteria that were applied [10]. Oncocytic papillary carcinoma may have a papillary or follicular structure. The papillary type is characterized by complex and branched papillae that are constituted by oncocytic cells that cover the thin fibrovascular stromal core. As for the oncocytic papillary carcinoma of follicular type, it is made up of macro- or micro-follicles with colloids at varying amounts. The oncocytic cells are generally polygonal; however they may also be columnar. Their cytoplasms are full, granular, pale and eosinophilic. Berho et al. suggested that the diagnosis of oncocytic papillary carcinoma be based on nuclear characteristics such as typical clear nucleus, characteristic intranuclearcytoplasmic inclusions and presence of nuclear grooves. These characteristics seem more important than the presence of papillae, the diagnostic criterion for papillary carcinoma [9].

The clinical behaviors of reported oncocytic tumors are variable. The American Cancer Society proposed that all oncocytic tumors of the thyroid be classified as malignant in 1950s. Most studies conducted in the aftermath indicated that oncocytic tumors could be classified adenoma or carcinoma by using morphological criteria, which are valuable in non-oncocytic follicular tumors. The lifetime mortality rate of oncocytic carcinomas (both follicular and papillary) are significantly higher than those that are non-oncocytic $[10,11]$.

In conclusion, metastasis should be considered in the first place when tumors with a morphology that is not very frequent in thyroid. The presence of diffuse lymphovascular invasions is a supportive finding in favor of metastatic tumors. We report the first case of synchronized occurrence of oncocytic variant of papillary carcinoma of the thyroid and metastatic squamous cell carcinoma.

\section{REFERENCES}

1. Basu S, Nair N, Borges AM. Squamous cell carcinoma of esophagus masquerading as solitary thyroid nodule. Indian J Cancer 2005;42:205-207.

2. Chen ED, Cheng P, Yan XQ, et al. Metastasis of distal esophageal carcinoma to the thyroid with presentation simulating primary thyroid carcinoma: a case report and review of the literature. World $\mathrm{J}$ Surg Oncol 2014;23:106.

3. Heffess CS, Wenig BM, Thompson LD. Metastatic renal cell carcinoma to the thyroid gland: a clinicopathologic study of 36 cases. Cancer 2002;95:1869-1878.

4. Dionigi G, Uccella S, Gandolfo M, et al. Solitary intrathyroidal metastasis of renal clear cell carcinoma in a toxic substernal multinodular goiter. Thyroid Res 2008;1:6.

5. Sindoni A, Rizzo M, Tuccari G, et al. Thyroid metastases from renal cell carcinoma: review of the literature. ScientificWorld Journal 2010;10:590-602.

6. Harcourt-webster JN. Secondary neoplasm of the thyroid presenting as a goitre. J Clin Pathol 1965;18:282287.

7. Vardar E, Erkan N, Bayol U, et al. Metastatic tumours to the thyroid gland: report of 3 cases and brief review of the literature. Radiol Oncol 2011;45:53-58.

8. Hashimoto K, Yamamoto H, Nakano T, et al. Tumorto-tumor metastasis: lung adenocarcinoma metastasizing to a follicular variant of papillary thyroid carcinoma. Pathol Int 2011;61:435-441.

9. Berho M, Suster S. The oncocytic variant of papillary carcinoma of the thyroid: a clinicopathologic study of 15 cases. Hum Pathol 1997;28:47-53.

10. Herrera MF, Hay ID, Wu PS, et al. Hürthle cell (oxyphilic) papillary thyroid carcinoma: a variant with more aggressive biologic behavior. World J Surg 1992;16:669-674;

11. Asa SL. My approach to oncocytic tumours of the thyroid. J Clin Pathol 2004;57:225-232. 